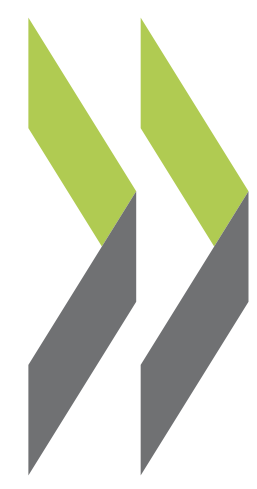

OECD Economics Department Working Papers No. 1474

\title{
Network service
}

deregulation

and manufacturing exports

in Greece

Christian Daude,

Christine de la Maisonneuve 
Organisation de Coopération et de Développement Économiques

Organisation for Economic Co-operation and Development

11-Jun-2018

ECONOMICS DEPARTMENT

English - Or. English

\section{NETWORK SERVICE DEREGULATION AND MANUFACTURING EXPORTS IN GREECE}

ECONOMICS DEPARTMENT WORKING PAPERS No. 1474

By Christian Daude and Christine de la Maisonneuve

OECD Working Papers should not be reported as representing the official views of the OECD or of its member countries. The opinions expressed and arguments employed are those of the author(s).

Authorised for publication by Álvaro Pereira, Acting Chief Economist, Economics Department.

All Economics Department Working Papers are available at www.oecd.org/eco/workingpapers.

JT03433299

This document, as well as any data and map included herein, are without prejudice to the status of or sovereignty over any territory, to the delimitation of international frontiers and boundaries and to the name of any territory, city or area. 
OECD Working Papers should not be reported as representing the official views of the OECD or of its member countries. The opinions expressed and arguments employed are those of the author(s).

Working Papers describe preliminary results or research in progress by the author(s) and are published to stimulate discussion on a broad range of issues on which the OECD works.

Comments on Working Papers are welcomed, and may be sent to OECD Economics Department, 2 rue André-Pascal, 75775 Paris Cedex 16, France, or by e-mail to eco.contact@ oecd.org.

All Economics Department Working Papers are available at www.oecd.org/eco/workingpapers.

This document and any map included herein are without prejudice to the status of or sovereignty over any territory, to the delimitation of international frontiers and boundaries and to the name of any territory, city or area.

The statistical data for Israel are supplied by and under the responsibility of the relevant Israeli authorities. The use of such data by the OECD is without prejudice to the status of the Golan Heights, East Jerusalem and Israeli settlements in the West Bank under the terms of international law.

\section{(c) OECD (2018)}

You can copy, download or print OECD content for your own use, and you can include excerpts from OECD publications, databases and multimedia products in your own documents, presentations, blogs, websites and teaching materials, provided that suitable acknowledgment of OECD as source and copyright owner is given. All requests for commercial use and translation rights should be submitted to rights@oecd.org 


\section{ABSTRACT/RÉSUMÉ \\ Network service deregulation and manufacturing exports in Greece}

Network sectors (energy, transport and communications) have undergone a process of liberalisation in Greece in more than a decade. This paper analyses the relationship between these reforms and the export performance of manufacturing industries. The analysis is based on firm-level data and performed between 1997 and 2013. An indicator of network sectors regulation is constructed which takes into account the manufacturing industry's reliance on each upstream sector. We find that streamlining regulations in network services in Greece has had an important positive impact on exports in downstream industries. Our estimates are robust to different specifications and estimation methods. In particular, this paper shows that the reforms would have a greater impact for firms with higher productivity.

This Working Paper relates to the 2016 OECD Economic Survey of Greece (www.oecd.org/eco/surveys/economic-survey-greece.htm).

JEL codes: C23, F1, L5, L8

Keywords: network industries, manufacturing firm's export, deregulation, firm level data

******

\section{Déréglementation des industries de réseau et exportations des industries manufacturières en Grèce}

Les industries de réseaux (énergie, transports et communications) ont connu un processus de libéralisation en Grèce depuis plus d'une décennie. Cet article analyse la relation entre ces réformes et les performances à l'exportation des industries manufacturières. L'analyse est basée sur des données au niveau de l'entreprise et réalisée entre 1997 et 2013. Un indicateur de la réglementation des industries de réseau est construit qui prend en compte la dépendance de l'industrie manufacturière à chaque secteur en amont. Nous constatons que la rationalisation des réglementations dans les services de réseau en Grèce a eu un impact positif important sur les exportations dans les industries en aval. Nos estimations sont robustes à différentes spécifications et méthodes d'estimation. En particulier, ce document montre que les réformes auraient un impact plus important sur les entreprises à productivité plus élevée.

Ce Document de travail se rapporte à l'Étude économique de la Grèce 2016

(www.oecd.org/fr/eco/etudes/etude-economique-greece.htm).

JEL codes: C23, F1, L5, L8

Mots-clés: industries de réseau, exportations des entreprises manufacturières, déréglementation, données des entreprises 


\section{TABLE OF CONTENTS}

\begin{tabular}{|c|}
\hline 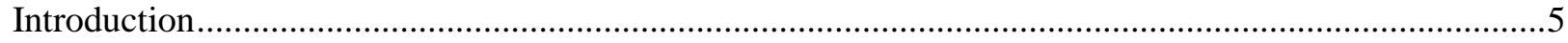 \\
\hline (2). \\
\hline Data and empirical model \\
\hline Firm data \\
\hline Services sector regulation index \\
\hline Empirical model \\
\hline Results. \\
\hline 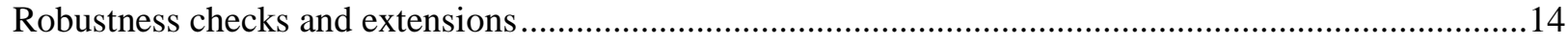 \\
\hline Conclusion \\
\hline
\end{tabular}

\section{Tables}

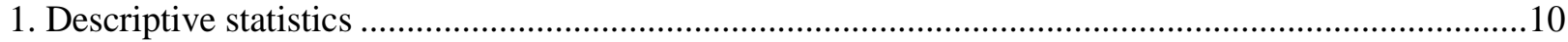

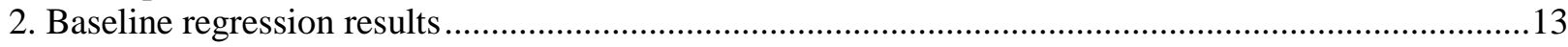

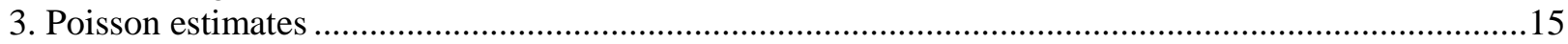

4. Sensitivity analysis: alternative dependent variable …..................................................................16

5. Sensitivity analysis: alternative specifications..............................................................................

\section{Figures}

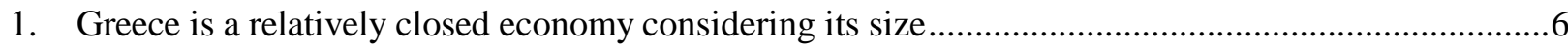

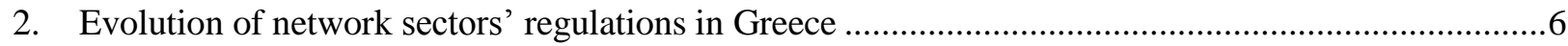

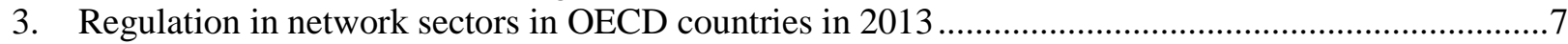

4. Network sectors are still subject to restrictive regulation in Greece ................................................8 
ECO/WKP(2018)22

\title{
NETWORK SERVICE DEREGULATION AND MANUFACTURING EXPORTS IN GREECE
}

\author{
By Christian Daude and Christine de La Maisonneuve ${ }^{1}$
}

\section{Introduction}

1. Since 2010, Greece has embarked on a series of structural reforms to deal with its fiscal challenges and loss of competitiveness. The reforms addressed primarily problems related to public finances and the labour market. Reforms to reduce the regulatory burden and improve the business climate were launched at a later stage and were less profound. As a consequence, resources have been kept in uncompetitive activities instead of creating incentives for moving towards more efficient or new ones (OECD , 2016). The empirical evidence shows that product market reforms are important to increasing productivity and boosting investment. In particular reforms in network sectors, can impact positively firms' productivity but also export performance (Bourles et al., 2013; and Bas, 2013).

2. Exports as a share of GDP in Greece are relatively low compared to OECD countries and given the small size of its economy. A simple regression with respect to GDP, would predict that, given the size of the economy, Greece's exports as a share of GDP should be around 60\%, twice its observed level (Figure 1). This empirical fact has been a characteristic of the Greek economy since decades. Furthermore, despite the process of internal devaluation that started in the aftermath of the global economy and financial crisis, the improvement in cost-competitiveness has failed to boost export performance as expected a priori, in part because it was not followed by a downwards adjustment of prices similar in size.

3. Many structural barriers and problems in infrastructure, access to finance or the legal system hamper the development of export activity (OECD, 2016). For instance, the cost and time involved in export procedures at the pre-customs and customs stages in Greece remain high (World Bank, 2015). The barriers to entrepreneurship as measured by the OECD Product Market Regulation indicator also reveal that Greece is more restrictive than many OECD countries. This is particularly the case for the complexity of regulatory procedures and the administrative burdens -especially for issuing licenses and permits for operating a business- on start-ups that are higher than the OECD average. The OECD Services Trade Restrictiveness Index (STRI), which measures regulations that inhibit cross-border trade in services, also shows that, in Greece, accounting services, broadcasting, maritime services and telecom have higher barriers than in OECD (Nordås and Rouzet, 2015). In particular, this paper shows that still high regulations in network industries affect overall export performance.

The authors were working on the Greek desk in the Economics Department at the time of writing this paper. The authors would like to thank Robert Ford, Peter Gal, Álvaro Pereira, Piritta Sorsa (Economics Department) and Hildegunn Nordas (Trade and Agriculture Directorate) for valuable comments. Special thanks go to Peter Gal and Valentine Millot for providing the dataset and Assa Fofana for editorial assistance (also from the Economics Department). 
Figure 1. Greece is a relatively closed economy considering its size

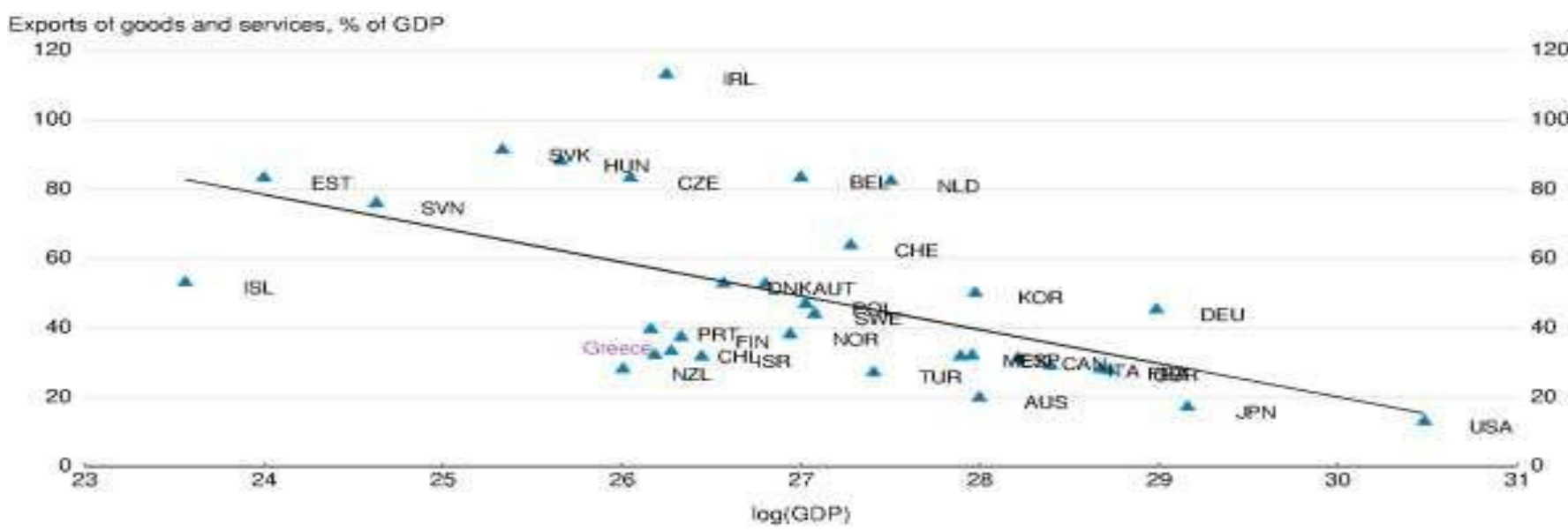

Source: OECD National accounts database.

4. Network sectors (energy, transport and communications) have undergone a process of liberalisation in Greece in the last decade (Figure 2). Nonetheless, these sectors are still more regulated than in most OECD countries (Figure 3). In particular, in rail and road transport, as well as electricity and gas, a combination of public ownership, barriers to entry and a significant vertical integration leads to relatively high costs that undermine the competitiveness of the rest of the economy (Figure 4). As we show below, the gains for firms, in particular in export activities would be substantial for moving closer to OECD best practices.

Figure 2. Evolution of network sectors' regulations in Greece

Index scale from 0 - 6 (least to most restrictive)

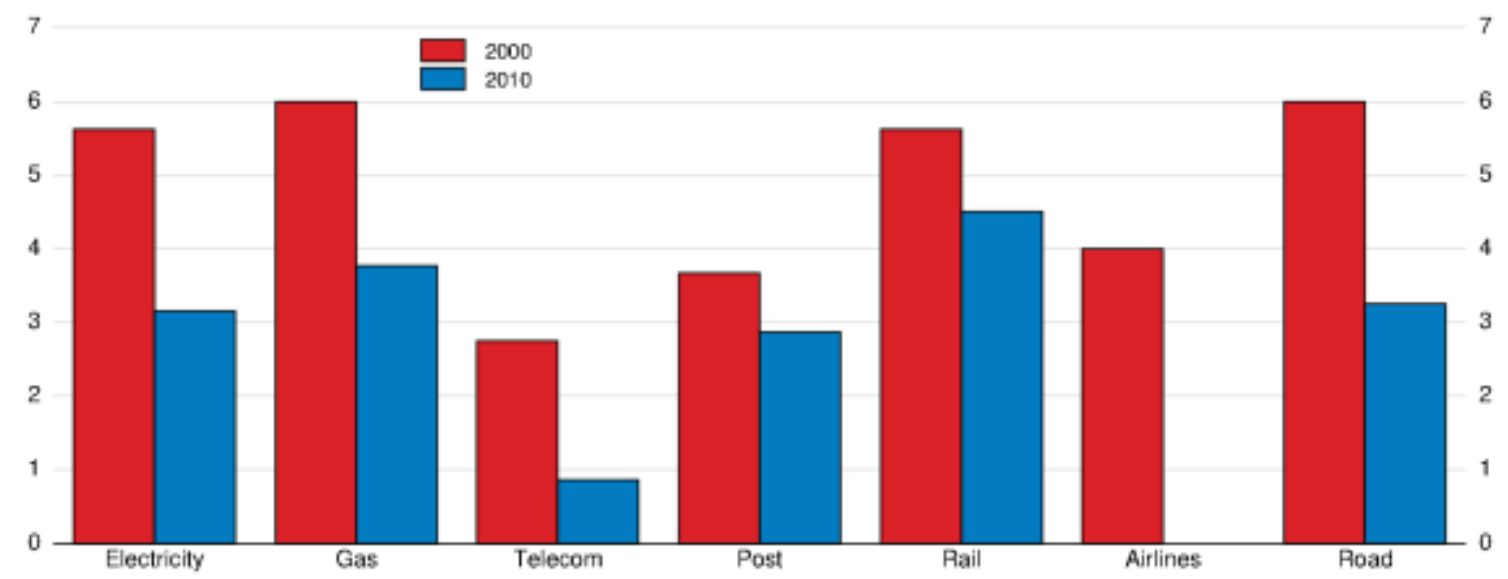

Source: OECD ETCR database. 
Figure 3. Regulation in network sectors in OECD countries in 2013

Index scale from 0 - 6 (least to most restrictive)

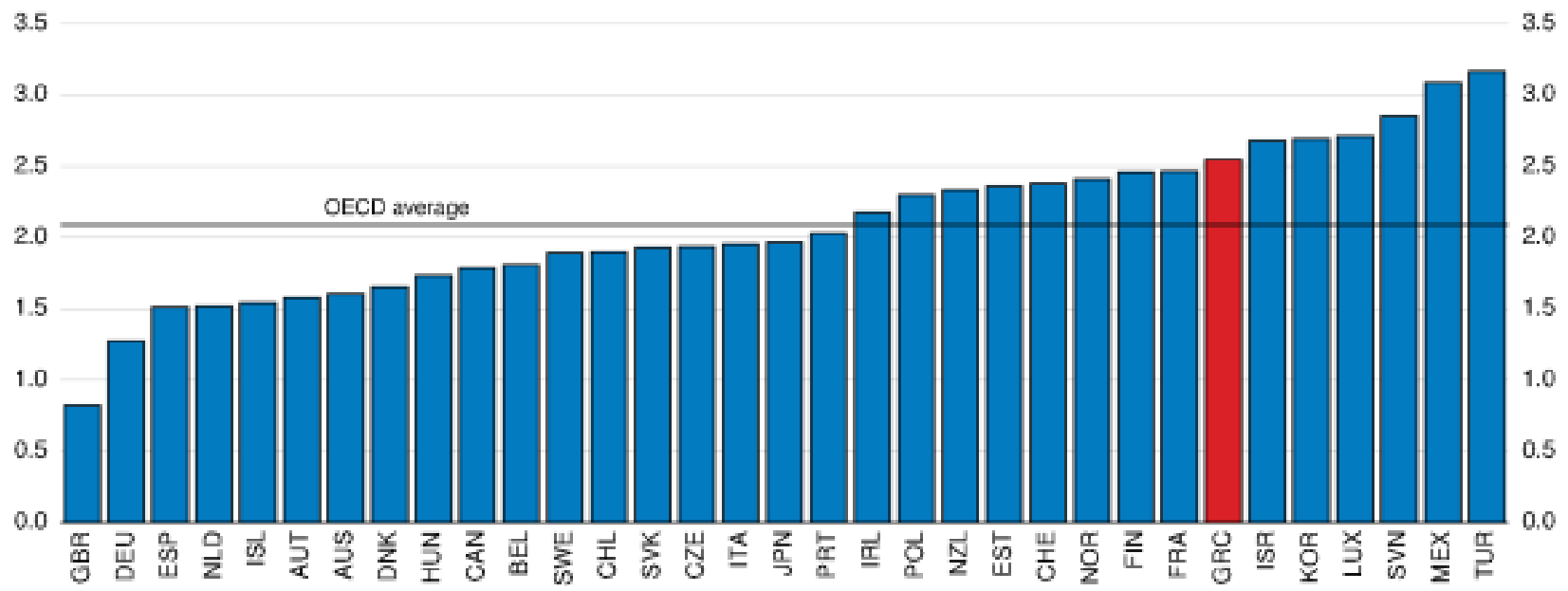

Source: OECD ETCR database.

5. There is an extensive empirical literature that analyses the impact of network sector regulations on the productivity of firms in downstream industries (e.g. Conway et al, 2006; Bourles et al, 2010). But fewer studies have looked at the impact of service deregulation on the export performance of firms. Following this recent strand in the literature, this paper explores the effect of the liberalisation in network sectors between 1997 and 2013 in Greece on firms' exports. The remainder of the paper is structured as follows. The first section provides a brief review of the literature. The second section describes the data and empirical strategy. The third and fourth sections present the results and sensitivity analysis and the last section concludes. 
Figure 4. Network sectors are still subject to restrictive regulation in Greece

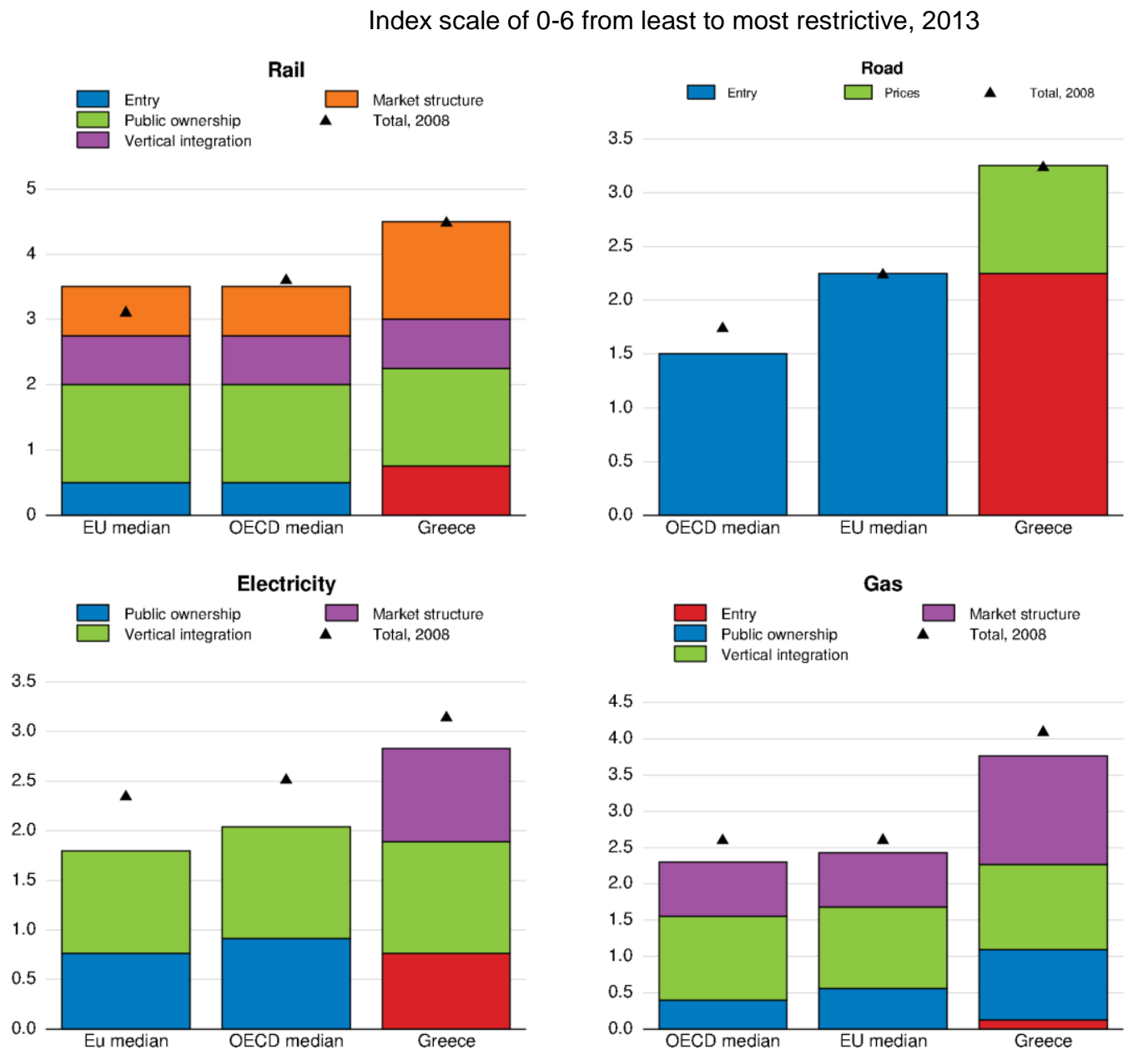

Source: OECD (2015) Product Market Regulation databas 


\section{Literature review}

6. Several related papers have analysed the impact of trade liberalisation for inputs and more general cost reductions in intermediate goods and services on firms' performance. For instance, Amiti and Konings (2007) show that a decrease in input tariffs in Indonesia leads to productivity gains for firms that import their inputs, beyond the gains from reducing output tariffs. Goldberg et al. (2009) provide evidence that trade reform have benefited firms in India by providing access to more and cheaper inputs but also to new input goods and varieties.

7. A strand of literature suggests that streamlining regulation in network industries can have an impact on the performance (productivity) of firms in those sectors (Boylaud, 2000, Gonenc and Nicoletti, 2000 and Lanau and Topalova, 2016). A series of OECD country-specific studies have also documented a positive effect of service-sector liberalisation reforms on firm's productivity in other sectors of the economy. Evidence for India shows that an increase in competition in upstream services can positively affect the performance of firms in downstream manufacturing industries through different channels: the reduction of production costs, access to higher-quality services, positive foreign spillovers and the access to new varieties of services (Bas, 2013). In particular, the liberalisation of transport and telecommunication sectors reduces trade costs faced by exporting firms (Bas, 2013). In Brazil, reforms targeting services that add value by favouring productivity and quality enhancements, as well as services that increase efficiency by reducing production costs, have strong potential to unlock manufacturing performance (Arbache, Rouzet and Spinelli, 2016). Nordås and Kim (2013) also show that the density of telecoms networks and the reliability of electricity supply stand out as the most crucial for competitive manufacturing.

8. Bourles et al (2013) provide evidence that anticompetitive regulations in upstream sectors significantly limited TFP growth in the 15 years prior to their study across OECD countries and that the effect was stronger for industries that are close to the productivity frontier. Arnold et al (2011a) show a positive relationship between services sector reform and the performance of domestic firms in downstream manufacturing in Czech Republic, mainly through the entry of foreign providers. Fernandes and Paunov (2012) showed that lifting restrictions to foreign direct investment in services led to an improvement in firm productivity in Chile. Similarly, Arnold et al. (2011b) find that banking, telecommunications, insurance and transport reforms have boosted the productivity of manufacturing firms in India. Lanau and Topalova (2016) show that deregulation in network sectors in Italy between 2003 and 2013 had a positive impact on value added and productivity of firms in these sectors and in firms using these intermediates in their production process. Finally, Bas and Causa (2013) find that services reforms enhanced downstream firms' productivity and the effect is stronger for those firms producing closer to the technological frontier in China.

9. Some new empirical studies have a similar focus to ours on the effects of deregulation in upstream service sectors on export performance in downstream manufacturing industries. Barone and Cingano (2011) find that service sector regulations have a significant negative impact on the growth rate of value added, productivity and exports of service-dependent industries in OECD countries. In a related paper, Correa-Lopez and Doménech (2014), using firm-level data for Spain, show that reducing anti-competitive regulation in the provision of upstream services has a positive and sizeable effect on the volume of exports of downstream firms. Their estimates indicate that deregulation is very beneficial for the export performance of large corporations, especially if they are foreign-owned multinationals, while the evidence for SMEs is much weaker. Finally, Bas (2013) finds that the reform of upstream services sector has increased the probability of exporting and the share of exports in total sales of firms producing in downstream manufacturing industries in India. All these results suggest that the effect of 
services liberalisation on manufacturing firms' export performance is stronger for initially more productive firms.

\section{Data and empirical model}

\section{Firm data}

10. This paper uses the ORBIS database (commercialised by Bureau Van Dijk). The ORBIS data are based on financial statements of firms as reported to institutions such as business registers, chambers of commerce or local credit institutions. These data have been cleaned and checked by the OECD Statistics Directorate to ensure consistency across countries (Ragoussis and Gonnard, 2012) and further reviewed by removing implausible values and outliers. One limitation of the database is that the coverage of small firms is significantly smaller than for large firms. In the case of Greece, the database covers around 5\% of all firms, while for firms with more than 250 employees it goes up to $60 \%$.

11. The analysis is performed using annual data between 1997 and 2013, the longest period for which reliable data are available for Greece. For robustness checks, we also carried out the analysis on a shorter time period (until 2007) to exclude the crisis years. Manufacturing sectors (23) are used at the 2 digits level. The main sector represented in the sample is food products and beverages, which is coherent with the share of this sector in the total manufacturing value added. Sensitivity analysis is performed including also the services sector.

12. In our baseline scenario the dependent variable is the export turnover of each firm (in logs). We, then, carry out sensitivity analysis with the export share defined as the ratio of export turnover to the operating revenue as a dependent variable. In terms of controls, we include the age of the firm, computed as the difference between the year of the survey and the year of the incorporation of the firm. We also include the number of employees and labour productivity (computed as value added divided by employees). Some descriptive statistics are displayed in Table 1.

Table 1. Descriptive statistics

\begin{tabular}{|l|c|c|c|}
\hline Firm's characteristics & Number of observations & Mean & Standard deviation \\
\hline Export turnover (Thousands of euros) & 272023 & 890.3 & $2.2 \mathrm{E}+04$ \\
\hline Export share & 270207 & $7.4 \%$ & $19.8 \%$ \\
\hline Age (in years) & 328076 & 17.0 & 14.2 \\
\hline Employees & 336802 & 50.6 & 459.7 \\
\hline Productivity (Thousands of euros) & 300546 & 160.8 & 145.8 \\
\hline
\end{tabular}

Source: ORBIS database.

\section{Services sector regulation index}

13. In order to measure regulation in network sectors, we rely on some specific components of the OECD Product Market Regulation indicator. The OECD PMR indicator is an economy-wide measure of product market regulation. It is complemented by a set of indicators that summarize information not 
by regulatory domain, but by sector (Koske et al, 2015). These indicators cover seven network sectors: telecom, electricity, gas, post, air transport, rail transport, and road transport. Usually, these indicators are aggregated into one indicator of energy, transport and communications regulation (ETCR) using equal weights. The index is constructed in a way that a lower index indicates a higher degree of liberalisation.

14. As discussed below in more detail, our identification strategy relies on the assumption that for technological reasons some sectors are more intensive in the use of intermediate inputs from network sectors than others. Therefore, in order to obtain a sector-specific measure of ECTR regulation, we need to combine the different intensity by sector with economy-wide ETCR regulations. In this paper, following Bas (2013), we constructed an indicator which takes into account the manufacturing industry's reliance on each upstream sector (energy, transport and communication). In particular, for each industry, an industryspecific services index is constructed by weighting each upstream industry sub-component of the ETCR indicator by the manufacturing industry's reliance. This weight is measured by the share of each of these service inputs used by each manufacturing industry on total input expenditures, based on Greece's input-output matrices. To reduce potential endogeneity issues between service input weights and firms' performance, we use the input-output matrix during the pre- sample period of the mid-1990s. Finally, the new service reform measure (ETCRN) for each manufacturing industry $s$ and year $t$ is the sum of the three weighted indicators and is given by:

$$
\operatorname{ETCRN}_{s, t}=\sum_{j} \omega_{j, s} \operatorname{ETCR}_{j, t}
$$

Where $\omega_{\mathrm{j}, \mathrm{s}}$ is the value share of sectorial input $\mathrm{j}$ (energy, transport and communication) used in the production of the final goods of manufacturing industry $\mathrm{s}$.

\section{Empirical model}

15. Bas (2013) presents a model that extends Melitz (2003) model by incorporating upstream network services, such as transport, telecommunications and energy, as intermediate inputs for final manufacturing goods. The model shows that reforms that lead to cost reductions in upstream service inputs increase the likelihood of exporting by manufacturing firms. Second, these reforms increase also export revenues of manufacturing firms. Finally, the effects are larger for firms that are more productive, just in the spirit of Melitz (2003) where firms that are more productive are more likely to export in the presence of fixed costs of doing so.

16. Using the new ETCRN index as a proxy for the cost of regulation in network industries for manufacturing industries, we investigate the relationship between the export turnover and services reforms by estimating the following linear model:

$$
\operatorname{exports}_{i, s, t}=\alpha_{1} \operatorname{ETCRN}_{s, t-1}+\alpha_{2} X_{i, t-1}+\mu_{i}+\vartheta_{t}+\varepsilon_{i, s, t},
$$

Where exports ${ }_{i, s, t}$ is the export turnover (or share of export to total sales) of firm $i$, in industry $s$, in year $t, E T C R N_{s, t-1}$ represents the regulation index of industry $s$, in year t-1 and $x_{i, t-1}$ is a set of firm level control variable. The latter are introduced to deal with potential omitted variables issues. Taking into account what has been found in the literature, we expect $\alpha_{1}$ to be negative. 


\section{Results}

17. Table 2 presents the baseline regression results using different specifications and estimation techniques. The first column shows the pooled-OLS estimates, including the age and size of the firm as controls. The results indicate a negative and statistically significant impact of ETCR regulations on export turnover. The estimate is also significant from an economic viewpoint. An increase in the stringency of ETCR regulations by one point - which is slightly above the standard deviation among OECD countries in the sample period $(0.84)$ - leads to a decline in exports by around $20 \%{ }^{1}$. Similarly, this estimate implies that if Greece would reform its network sectors regulations such that its ETCR restrictiveness index (2.55 in 2013) move to the score of the best performer in the OECD - the United Kingdom with a value of 0.79 in 2013 (see Figure 3 above) - export turnover would increase by around $47 \%$.

18. The results are similar, with a slightly larger impact of ETCR, when including sector fixed effects to control for unobserved sectorial characteristics that might be correlated with the other regressors (column 2 of Table 2). Therefore, the results are robust to controlling for sectorial characteristics, which in particular might be correlated with the ETCR variable - as this variable varies across sectors and time. When including the firm's level of productivity as a regressor (column 3 of Table 2), the ETCR variable continues to be statistically significant, but the point estimate is an order of magnitude smaller. This is in line with the idea that ETCR regulations affect export turnover mainly by reducing productivity, as the theory and evidence discussed in the literature above shows for cross-country sector data (Bourles et al., 2010). 
ECO/WKP(2018)22

Table 2. Baseline regression results

Dependent variable: Export turnover (in logs)

\begin{tabular}{|c|c|c|c|c|c|c|c|c|}
\hline & Pooled OLS & Pooled OLS & Pooled OLS & Fixed effects & Fixed effects & $\begin{array}{l}\text { Random } \\
\text { effects }\end{array}$ & $\begin{array}{l}\text { Random } \\
\text { effects }\end{array}$ & $\begin{array}{l}\text { Fixed effects } \\
\text { (Before 2008) }\end{array}$ \\
\hline & (1) & (2) & (3) & (4) & (5) & (6) & (7) & (8) \\
\hline Lagged ETCR & $\begin{array}{c}-0.220^{\star \star *} \\
(0.01)\end{array}$ & $\begin{array}{c}-0.230^{\star \star *} \\
(0.01)\end{array}$ & $\begin{array}{c}-0.025^{\star \star \star} \\
(0.01)\end{array}$ & $\begin{array}{c}-0.739^{\star \star \star} \\
(0.10)\end{array}$ & $\begin{array}{c}-0.443^{\star \star \star} \\
(0.07)\end{array}$ & $\begin{array}{c}-0.700^{\star \star \star} \\
(0.10)\end{array}$ & $\begin{array}{c}-0.400^{\star \star \star} \\
(0.07)\end{array}$ & $\begin{array}{c}-0.284^{* *} \\
(0.13)\end{array}$ \\
\hline Log(Age) & $\begin{array}{c}-0.183^{\star \star \star} \\
(0.01)\end{array}$ & $\begin{array}{c}-0.185^{\star \star \star} \\
(0.01)\end{array}$ & $\begin{array}{c}-0.117^{\star \star \star} \\
(0.01)\end{array}$ & $\begin{array}{c}0.086^{\star \star} \\
(0.04)\end{array}$ & $\begin{array}{l}-0.026 \\
(0.03)\end{array}$ & $\begin{array}{l}0.037 \\
(0.03)\end{array}$ & $\begin{array}{c}-0.044^{\star *} \\
(0.02)\end{array}$ & $\begin{array}{c}0.184^{\star \star \star} \\
(0.06)\end{array}$ \\
\hline Log(Employees) & $\begin{array}{c}1.079^{\star \star \star} \\
(0.01)\end{array}$ & $\begin{array}{c}1.045^{\star \star *} \\
(0.01)\end{array}$ & $\begin{array}{c}1.086^{\star \star *} \\
(0.01)\end{array}$ & $\begin{array}{c}0.522^{\star \star \star} \\
(0.02)\end{array}$ & $\begin{array}{c}0.695^{\star \star \star} \\
(0.01)\end{array}$ & $\begin{array}{c}0.588^{\star \star \star *} \\
(0.02)\end{array}$ & $\begin{array}{c}0.758^{\star \star *} \\
(0.01)\end{array}$ & $\begin{array}{c}0.598^{\star \star \star} \\
(0.14)\end{array}$ \\
\hline Lagged Log(Productivity) & & & $\begin{array}{l}0.935^{\star \star \star} \\
(0.01)\end{array}$ & & $\begin{array}{l}0.603^{\star \star \star} \\
(0.01)\end{array}$ & & $\begin{array}{l}0.637^{\star \star \star} \\
(0.01)\end{array}$ & \\
\hline Constant & $\begin{array}{c}10.845^{\star \star \star} \\
(0.05)\end{array}$ & $\begin{array}{c}11.960^{\star \star \star} \\
(0.17)\end{array}$ & $\begin{array}{l}-0.189 \\
(0.18)\end{array}$ & $\begin{array}{c}13.063^{\star \star \star} \\
(0.31)\end{array}$ & $\begin{array}{c}5.017^{\star \star \star} \\
(0.30)\end{array}$ & $\begin{array}{c}13.401^{\star \star \star} \\
(0.40)\end{array}$ & $\begin{array}{c}4.742^{* * *} \\
(0.36)\end{array}$ & $\begin{array}{c}11.670^{\star \star \star} \\
(0.67)\end{array}$ \\
\hline Firm effects & no & no & no & yes & yes & no & no & yes \\
\hline Year effects & no & no & no & yes & yes & yes & yes & yes \\
\hline Sector effects & no & yes & yes & no & no & yes & yes & no \\
\hline Number of observations & $3.8 \mathrm{e}+04$ & $3.8 \mathrm{e}+04$ & $3.6 e+04$ & $3.8 \mathrm{e}+04$ & $3.6 e+04$ & $3.8 \mathrm{e}+04$ & $3.6 e+04$ & $2.3 e+04$ \\
\hline $\mathrm{R} 2$ & 0.371 & 0.428 & 0.567 & 0.184 & 0.354 & & & 0.114 \\
\hline
\end{tabular}

Notes: Robust standard errors in parentheses. ${ }^{* \star *} \mathrm{p}<0.01,{ }^{* \star} \mathrm{p}<0.05,{ }^{*} \mathrm{p}<0.10$.

19. The pooled OLS regressions might render a biased estimate of the ETCR effect, because of the existence of omitted firm-level variables that affect exports and are correlated with ETCR restrictions. This could be the case if exporting requires incurring in a fixed cost in order to getting to know markets and customers or upgrading products to meet international standards. Only the more productive firms will undertake this investment and become an exporter (Melitz, 2003). Productivity is also likely to be negatively affected by the ETCR restrictions, for example through higher energy costs that distort the use of production factors or through market power by ETCR firms that reduces profitability in downstream industries and therefore incentives to innovate or gain efficiency. Therefore, it is important to test the robustness of results. Columns 4 and 5 of Table 2 provide some robustness checks by including year fixed effects- that would account for unobserved common factors across firms for example related to the business cycle, as well as firm level fixed effects and sector fixed effects, which control for part of these potential biases. Overall, these estimates show a significantly larger impact of ETCR restrictions on exports that the pooled OLS estimates. For example, the estimates in column 4 imply that a one-point reduction in ETCR restrictions would increase exports by 52\%. Column 6 and 7 shows the estimates of the model using random firm effects instead of fixed effects. The results are very similar to the fixed effects estimates.

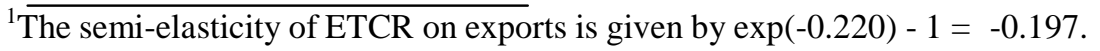


20. Another concern with the results is that part of the sample includes the crisis period during which the Greek economy collapsed. This might reflect very different firm and export dynamics that could affect the results. In order to test the stability of the baseline results, column 8 of Table 2 presents the estimates including year and sector- fixed effects and firm random effects, only for the years before the crisis in our sample. The results show that the ETCR coefficient remains significant. While its size is smaller, it still implies a considerable impact of ETCR regulations on exports, with a one-point reduction in ETCR stringiness leading to a $26 \%$ increase in export turnover.

\section{Robustness checks and extensions}

21. The previous estimates might suffer from an attenuation bias. The exclusion of firms that do not export at all from the previous analysis might be introducing an attenuation bias in the regressions presented in Table 2, as high costs driven by ETCR regulations might not only cause firms to export less but also induce some of them to not engage in export activities at all. Actually, more that $40 \%$ of the observations in our dataset are zeroes. Therefore, the estimates above should be considered a lower bound of the impact of ETCR regulations on exports in Greece. In order to analyse the sensitivity to the exclusion of the firms that do not export at all, we use an alternative estimator, used also in the trade literature to deal with the problem of non-negative dependent variables. In particular, we follow Santos Silva and Tenreyro (2006) by using a Poisson Pseudo-maximum-likelihood (PPML) estimator.

22. Table 3 shows that the results are robust to using this alternative estimation method. The ETCR coefficient is statistically significant and negative for all specifications. ${ }^{2}$ Furthermore; in general the point estimate is larger than the equivalent estimates presented in Table 2, which confirms the existence of an attenuation bias in the estimates that exclude the zero export values. According to the PPML results, a one-point reduction in ETCR regulatory barriers in Greece would increase export turnover by between $11 \%$ and $61 \%$ (columns 1 and 4 , which are the minimum and maximum point estimates).

\footnotetext{
${ }^{2}$ Sector dummies had to be omitted in most estimations because of convergence problems of the algorithm.
} 
ECO/WKP(2018)22

Table 3. Poisson estimates

Dependent variable: Export turnover

\begin{tabular}{|c|c|c|c|c|c|c|}
\hline & Pooled OLS & Pooled OLS & Pooled OLS & Fixed effects & Fixed effects & $\begin{array}{l}\text { Fixed effects } \\
\text { (Before 2008) }\end{array}$ \\
\hline & (1) & $(2)$ & (3) & (4) & (5) & (6) \\
\hline Lagged ETCR & $\begin{array}{c}-0.125^{\star \star} \\
(0.05)\end{array}$ & $\begin{array}{c}-0.199^{\star * \star} \\
(0.06)\end{array}$ & $\begin{array}{c}0.105^{\star \star \star} \\
(0.02)\end{array}$ & $\begin{array}{c}-0.946^{\star \star \star} \\
(0.30)\end{array}$ & $\begin{array}{c}-0.474^{\star \star \star} \\
(0.12)\end{array}$ & $\begin{array}{c}-1.135^{\star \star \star} \\
(0.21)\end{array}$ \\
\hline $\log ($ Age $)$ & $\begin{array}{c}0.108^{* * *} \\
(0.03)\end{array}$ & $\begin{array}{c}0.117^{* * *} \\
(0.04)\end{array}$ & $\begin{array}{c}-0.067^{* * *} \\
(0.02)\end{array}$ & $\begin{array}{c}-0.329^{*} \\
(0.17)\end{array}$ & $\begin{array}{l}-0.112 \\
(0.08)\end{array}$ & $\begin{array}{l}0.050 \\
(0.12)\end{array}$ \\
\hline Log(Employees) & $\begin{array}{c}1.207^{\star \star *} \\
(0.04)\end{array}$ & $\begin{array}{c}0.984^{\star * *} \\
(0.02)\end{array}$ & $\begin{array}{c}1.000^{\star \star *} \\
(0.01)\end{array}$ & $\begin{array}{c}0.401^{* * *} \\
(0.04)\end{array}$ & $\begin{array}{c}0.653^{\star * *} \\
(0.03)\end{array}$ & $\begin{array}{c}0.402^{\star \star \star} \\
(0.13)\end{array}$ \\
\hline Lagged Log(Productivity) & & & $\begin{array}{c}0.955^{\star * *} \\
(0.03)\end{array}$ & $\boldsymbol{r}$ & $\begin{array}{c}0.567^{* * *} \\
(0.03)\end{array}$ & \\
\hline Constant & $\begin{array}{c}9.873^{* * *} \\
(0.22)\end{array}$ & $\begin{array}{c}-18.343^{* * *} \\
(0.29)\end{array}$ & $\begin{array}{c}-1.685^{* * *} \\
(0.37)\end{array}$ & & & \\
\hline Firm effects & no & no & no & yes & yes & yes \\
\hline Year effects & no & no & no & yes & yes & yes \\
\hline Sector effects & no & yes & yes & no & no & no \\
\hline Number of observations & $6.4 \mathrm{e}+04$ & $6.4 \mathrm{e}+04$ & $6.0 e+04$ & $4.3 e+04$ & $4.1 e+04$ & $2.6 e+04$ \\
\hline $\mathrm{R} 2$ & 0.527 & 0.632 & 0.690 & & & \\
\hline
\end{tabular}

Notes: Robust standard errors in parentheses. ${ }^{* * *} p<0.01,{ }^{* *} p<0.05,{ }^{*} p<0.10$.

23. Next, we analyse if there are differences in the effect of ETCR regulations across firms. Columns 2 and 3 of Table 4 present the fixed effects estimate including an interaction between ETCR and productivity and the size of the firm measured by its employees, respectively. The estimates in column 2 show that the interaction between the productivity level of the firm and the ETCR variable is negative and significant. This means that ETCR restrictions are more stringent on firms with high productivity. This is consistent with the literature that points to the fact that more productive firms are more likely to engage in exports. Regarding size, the estimates in column 3 show that there is no differential effect of ETCR across firm size.

24. An alternative dependent variable is to consider the share of export turnover in total turnover. Considering this variable allows us to focus on the question whether ETCR regulations have a stronger effect on exports than on total sales. Columns 4 to 8 of table 4 focus on this issue for different specifications and estimation methods considered above. Overall, the results indicate that the point estimate tends to be negative, although it is not always significant. Therefore, the evidence seems to indicate that, while the effect of ETCR regulations seems to be slightly stronger on exports than total sales, this differential effect seems to be relatively small. Therefore, ETCR deregulations appear to benefit firms not only by making them more competitive in external markets, but also allow them to expand in the domestic market at a similar pace. 
ECO/WKP(2018)22

Table 4. Sensitivity analysis: alternative dependent variable

\begin{tabular}{|c|c|c|c|c|c|c|}
\hline Dependent variable & $\begin{array}{l}\text { Log (Export } \\
\text { turnover) }\end{array}$ & $\begin{array}{l}\text { Log (Export } \\
\text { turnover) }\end{array}$ & $\begin{array}{l}\text { Log (Export } \\
\text { turnover) }\end{array}$ & $\begin{array}{l}\log (\text { Export } \\
\text { share) }\end{array}$ & $\begin{array}{l}\log (\text { Export } \\
\text { share) }\end{array}$ & $\begin{array}{l}\log (\text { Export } \\
\text { share) }\end{array}$ \\
\hline & Fixed effects & Fixed effects & Fixed effects & Pooled OLS & Fixed effects & Random effects \\
\hline & (1) & $(2)$ & (3) & (4) & (5) & (6) \\
\hline Lagged ETCR & $\begin{array}{c}-0.443^{\star \star *} \\
(0.07)\end{array}$ & $\begin{array}{c}-0.199^{\star *} \\
(0.08)\end{array}$ & $\begin{array}{c}-0.415^{\star \star \star} \\
(0.07)\end{array}$ & $\begin{array}{c}-0.048^{\star \star \star} \\
(0.01)\end{array}$ & $\begin{array}{l}-0.009 \\
(0.05)\end{array}$ & $\begin{array}{l}-0.005 \\
(0.05)\end{array}$ \\
\hline $\log ($ Age $)$ & $\begin{array}{l}-0.026 \\
(0.03)\end{array}$ & $\begin{array}{l}-0.023 \\
(0.03)\end{array}$ & $\begin{array}{l}-0.014 \\
(0.03)\end{array}$ & $\begin{array}{c}-0.105^{\star * *} \\
(0.01)\end{array}$ & $\begin{array}{l}-0.036 \\
(0.02)\end{array}$ & $\begin{array}{c}-0.050^{\star *} \\
(0.02)\end{array}$ \\
\hline Log(Employees) & $\begin{array}{c}0.695^{\star \star *} \\
(0.01)\end{array}$ & $\begin{array}{c}0.686^{\star * *} \\
(0.01)\end{array}$ & $\begin{array}{c}0.727^{\star \star *} \\
(0.03)\end{array}$ & $\begin{array}{c}0.107^{* \star *} \\
(0.01)\end{array}$ & $\begin{array}{c}0.055^{\star * \star} \\
(0.01)\end{array}$ & $\begin{array}{c}0.058^{\star \star \star} \\
(0.01)\end{array}$ \\
\hline Lagged Log(Productivity) & $\begin{array}{c}0.603^{\star * *} \\
(0.01)\end{array}$ & $\begin{array}{c}0.708^{\star \star *} \\
(0.03)\end{array}$ & $\begin{array}{c}0.603^{\star * *} \\
(0.01)\end{array}$ & $\begin{array}{l}0.010 \\
(0.01)\end{array}$ & $\begin{array}{c}0.041^{* * *} \\
(0.01)\end{array}$ & $\begin{array}{c}0.041^{* * *} \\
(0.01)\end{array}$ \\
\hline ETCR * Lagged Log(Productivity) & & $\begin{array}{c}-0.029^{\star * *} \\
(0.01)\end{array}$ & & & & \\
\hline ETCR * Log(Employees) & & & $\begin{array}{l}-0.010 \\
(0.01)\end{array}$ & & & \\
\hline Constant & $\begin{array}{c}5.017^{* * *} \\
(0.30)\end{array}$ & $\begin{array}{c}4.096^{\star * *} \\
(0.35)\end{array}$ & $\begin{array}{c}4.888^{* * *} \\
(0.31)\end{array}$ & $\begin{array}{c}-1.128^{\star \star *} \\
(0.17)\end{array}$ & $\begin{array}{c}-2.396^{\star * *} \\
(0.22)\end{array}$ & $\begin{array}{c}-1.870^{\star \star \star} \\
(0.31)\end{array}$ \\
\hline Firm effects & yes & yes & yes & no & yes & no \\
\hline Year effects & yes & yes & yes & no & yes & yes \\
\hline Sector effects & no & no & no & yes & no & yes \\
\hline $\mathrm{N}$ & $3.6 e+04$ & $3.6 e+04$ & $3.6 e+04$ & $3.6 e+04$ & $3.6 e+04$ & $3.6 e+04$ \\
\hline $\mathrm{R} 2$ & 0.354 & 0.356 & 0.355 & 0.093 & 0.019 & \\
\hline
\end{tabular}

Notes: Robust standard errors in parentheses. ${ }^{* * *} p<0.01,{ }^{* *} p<0.05,{ }^{*} p<0.10$. 
25. Table 5 presents some alternative specifications. In our baseline, we used Greece's input-output tables to calculate the input intensity of network services by manufacturing sector for a year prior to the period analysed. As a robustness check, we also calculated the same indicator but using the input-output table from the United States which can be considered as, or close to, the technology frontier (column 1). This test solves the endogeneity problem and in addition captures the "ideal" input-output coefficients with optimal technology choices. We also tried to lag our indicator by 3 years instead of one as it can take more than a year for a change in regulation to have a positive impact on the performance in a downstream sector (column 2). We clustered standard errors at the level of the explanatory variable (column 3). Our results are robust to all these specifications. Regarding firms' decision to export, we performed a probit regression to evaluate the relationship between the probability of exporting and the independent variables. In this specification also, the liberalisation of network sectors increases the probability of exporting (column 4).

Table 5. Sensitivity analysis: alternative specifications

\begin{tabular}{|c|c|c|c|c|}
\hline Dependent variable & Log (Export turnover) & Log (Export turnover) & Log (Export turnover) & Export dummy ${ }^{1}$ \\
\hline & Fixed effects & Fixed effects & Pooled OLS & Probit \\
\hline & (1) & (2) & (3) & (4) \\
\hline Lagged ETCR & & & $\begin{array}{c}-0.025^{\star \star} \\
(0.01)\end{array}$ & $\begin{array}{c}-0.585^{\star \star \star} \\
(0.04)\end{array}$ \\
\hline ETCR lagged by 3 years & & $\begin{array}{c}-0.249^{\star \star *} \\
(0.05)\end{array}$ & & \\
\hline Lagged ETCR calculated with US weights & $\begin{array}{c}-0.387^{* * *} \\
(0.04)\end{array}$ & & & \\
\hline $\log ($ Age $)$ & $\begin{array}{l}-0.026 \\
(0.03)\end{array}$ & $\begin{array}{l}-0.039 \\
(0.04)\end{array}$ & $\begin{array}{c}-0.117^{\star \star \star} \\
(0.01)\end{array}$ & $\begin{array}{c}0.098^{\star \star \star} \\
(0.01)\end{array}$ \\
\hline Log(Employees) & $\begin{array}{c}0.697^{* * *} \\
(0.01)\end{array}$ & $\begin{array}{c}0.659^{\star * *} \\
(0.01)\end{array}$ & $\begin{array}{c}1.086^{\star * *} \\
(0.02)\end{array}$ & $\begin{array}{c}0.249^{\star * *} \\
(0.01)\end{array}$ \\
\hline Lagged Log(Productivity) & $\begin{array}{c}0.603^{\star \star \star} \\
(0.01)\end{array}$ & $\begin{array}{c}0.575^{\star \star \star} \\
(0.01)\end{array}$ & $\begin{array}{c}0.935^{\star \star \star} \\
(0.02)\end{array}$ & $\begin{array}{c}0.239^{\star \star \star} \\
(0.01)\end{array}$ \\
\hline _cons & $\begin{array}{c}4.778^{\star \star \star} \\
(0.25)\end{array}$ & $\begin{array}{c}4.967^{\star \star \star} \\
(0.29)\end{array}$ & $\begin{array}{l}-0.189 \\
(0.27)\end{array}$ & $\begin{array}{c}-1.911^{\star \star \star} \\
(0.13)\end{array}$ \\
\hline Firm effects & yes & yes & no & no \\
\hline Year effects & yes & yes & no & yes \\
\hline Sector effects & no & no & yes & no \\
\hline Number of observations & 35911 & 28284 & 35911 & 60211 \\
\hline R2 & 0.35 & 0.35 & 0.57 & \\
\hline
\end{tabular}

Notes: Robust standard errors in parentheses. ${ }^{* *} p<0.01,{ }^{* *} p<0.05,{ }^{*} p<0.10$.

1. Dummy variable which takes the value 1 if the firm is an exporter and 0 if not.

26. A final extension of our analysis is to look at service exports instead of manufacturing as we have done so far. A priori, we would expect that ETCR regulations are more stringent for manufacturing exports, because these industries are more intensive in the use of energy and service exports require much less transport services and logistics than goods. When undertaking the same analysis as before, but using services exports by firms instead of manufacturing, we do not find any systematically significant effect of ETCR regulations on exports. Therefore, ETCR reforms that reduce excessive regulation in these network sectors would boost primarily manufacturing exports without any significant impact on service exports. 


\section{Conclusion}

27. The evidence presented in this paper shows that streamlining regulations in network services in Greece has had an important positive impact on exports in manufacturing industries during the period reviewed. Given that Greece still presents significantly higher levels of restrictive regulations in these sectors compared to the best performers in the OECD and EU, reforms in network sectors are a promising way to foster the competitiveness of manufacturing industries. Our estimates are robust to different specifications and estimation methods.

28. In particular, this paper shows that ETCR reforms would have a greater impact for firms with higher productivity, the most productive firms exporting more and the most productive among nonexporters starting to export. In this sense, based on the evidence for other countries, ETCR reforms would probably raise overall productivity in Greece, which would also foster output growth. 


\section{BIBLIOGRAPHY}

Amiti, Mary, Konings, Joseph, 2007, "Trade liberalization, intermediate inputs, and productivity: evidence from Indonesia”, American Economic Review ,97 (5), 1611-1638.

Arbache, J., D. Rouzet and F. Spinelli (2016), “The Role of Services for Economic Performance in Brazil”, OECD Trade Policy Papers, No. 193, OECD Publishing, Paris. http://dx.doi.org/10.1787/5jlpl4nx0ptc-en

Arnold, J., Javorcik, B., and Mattoo, A. (2011a), "Does services liberalization benefit manufacturing firms? Evidence from the Czech Republic", Journal of International Economics, 85(1).

Arnold, J., Javorcik, B., Lipscomb, M., and Mattoo, A. (2011b), "Services reform and manufacturing performance: Evidence from India", CEPR Discussion Paper 8011.

Barone, G., Cingano, F., 2011, "Service regulation and growth: Evidence from OECD countries", Economic Journal 121, 931-957.

Bas M. (2013), "Does services liberalization affect manufacturing firms' export performance? Evidence from India", Document de travail No 17, CEPII, June.

Bas M. and Causa O. (2013), "Trade and product market policies in upstream sectors and productivity in downstream sectors: Firm-level evidence from China", Journal of Comparative Economics 41 (2013) 843-862.

Bourlès, R. Cette, G., Lopez, J., Mairesse J. and G. Nicoletti., (2010), "Do Product Market Regulations in Upstream Sectors Curb Productivity Growth?", Panel Data Evidence for OECD Countries" NBER Working Paper, 16520, National Bureau of Economic Research, Cambridge MA, July.

Bourlès, R., Cette, G., Lopez, J., Mairesse, J., Nicoletti, G. (2013), « Do product market regulations in upstream sectors curb productivity growth? Panel data evidence for OECD Countries", Review of Economics and Statistics 95, 1750-1768.

Boylaud, O. (2000), "Regulatory Reform in Road Freight and Retail Distribution", OECD Economics Department Working Papers, No. 255, OECD Publishing, Paris.

Conway, P., D. de Rosa, G. Nicoletti and F. Steiner (2006): "Product Market Regulation and Productivity Convergence", OECD Economic Studies No. 43: 39-76.

Correa-López and Doménech, 2014, "Does anti-competitive service sector regulation harm exporters?

Evidence from manufacturing firms in Spain", BBVA Working Paper No 14/13.

Fernandes, A. and Paunov, C. (2012). Foreign direct investment in services and manufacturing productivity: Evidence for Chile, Journal of Development Economics, 97:305-321.

Goldberg, Pinelopi, Khandelwal, Amit, Pavcnik, Nina, Topalova, Petia, 2009, “Trade Liberalization and New Imported Inputs”, American Economic Review Papers and Proceedings 99 (2), 494-500.

Gönenç, R. and G. Nicoletti (2000), "Regulation, Market Structure and Performance in Air Passenger Transportation”, OECD Economics Department Working Papers, No. 254, OECD Publishing, Paris. 
Koske, I. et al. (2015), “The 2013 update of the OECD's database on product market regulation: Policy insights for OECD and non-OECD countries", OECD Economics Department Working Papers, No. 1200, OECD Publishing.

Lanau S. and P. Topalova (2016), "The Impact of Product Market Reforms on Firm Productivity in Italy”, IMF Working Paper, WP/16/119.

Melitz, M. (2003), “The Impact of Trade on Intra-Industry Reallocations and Aggregate Industry Productivity," Econometrica, 71: 1695-1725.

Nordås, H. and Y. Kim (2013), “The Role of Services for Competitiveness in Manufacturing”, OECD Trade Policy Papers, No. 148, OECD Publishing, Paris.

http://dx.doi.org/10.1787/5k484xb7cx6b-en

Nordås, H. K. and D. Rouzet (2015), “The Impact of Services Trade Restrictiveness on Trade Flows: First

Estimates", OECD Trade Policy Papers, No. 178, OECD Publishing, Paris.

OECD (2016), OECD Economic Surveys: Greece 2016, OECD Publishing, Paris.

http://dx.doi.org/10.1787/eco_surveys-grc-2016-en.

Ragoussis, A. and E. Gonnard (2012), "The OECD-ORBIS Database: Treatment and benchmarking procedures", Mimeo.

Santos Silva, J.M.C. and S. Tenreyro (2006), "The Log of Gravity," Review of Economics and Statistics , 88(4), 641-658.

World Bank (2015). Doing Business 2016: Measuring Regulatory Quality and Efficiency. Washington, DC: World Bank. 